\title{
Interleukin-10 Prevents Glutamate-Mediated Cerebellar Granule Cell Death by Blocking Caspase-3-Like Activity
}

\author{
Alessia Bachis, ${ }^{1,4}$ Anna M. Colangelo, ${ }^{1}$ Stefano Vicini, ${ }^{2}$ Pylord P. Doe, ${ }^{2}$ Maria A. De Bernardi, ${ }^{3}$ Gary Brooker, ${ }^{3}$ \\ and Italo Mocchetti ${ }^{1,4}$ \\ Departments of ${ }^{1}$ Neuroscience and ${ }^{2}$ Physiology, Georgetown University, Washington, DC 20007, ${ }^{3}$ Department of Biology, \\ Johns Hopkins University, Baltimore, Maryland 21218, and 4 University of Cagliari, School of Pharmacy, 09124 Cagliari, Italy
}

Interleukin-10 (IL-10) has been shown to reduce neuronal degeneration after CNS injury. However, the molecular mechanisms underlying the neuroprotective properties of this cytokine are still under investigation. Glutamate exacerbates secondary injury caused by trauma. Thus, we examined whether IL-10 prevents glutamate-mediated cell death. We used rat cerebellar granule cells in culture because these neurons undergo apoptosis upon exposure to toxic concentrations of glutamate (100-500 $\mu \mathrm{M})$ or NMDA $(300 \mu \mathrm{M})$. Pretreatment of cerebellar granule cells with IL-10 (1-50 ng/ml) elicited a dose- and timedependent reduction of glutamate-induced excitotoxicity. Most importantly, IL-10 reduced the number of apoptotic cells when added to the cultures together or $1 \mathrm{hr}$ after glutamate. Using patch-clamping and fluorescence $\mathrm{Ca}^{2+}$ imaging techniques, we examined whether IL-10 prevents glutamate toxicity by blocking the function of NMDA channel. IL-10 failed to affect NMDA channel properties and to reduce NMDA-mediated rise in intracellular $\mathrm{Ca}^{2+}$. Thus, this cytokine appears to prevent glutamate toxicity by a mechanism unrelated to a blockade of NMDA receptor function. Various proteases, such as caspase-3, and transcription factors, such as nuclear factor $\kappa \mathrm{B}$ $(\mathrm{NF}-\kappa \mathrm{B})$, have been proposed to participate in glutamatemediated apoptosis. Thus, we examined whether IL-10 modulates the activity of these apoptotic markers. IL-10 blocked both the glutamate-mediated induction of caspase-3 as well as $N F-\kappa B$ DNA binding activity, suggesting that the neuroprotective properties of IL-10 may rely on its ability to block the activity of proapoptotic proteins.

Key words: apoptosis; $\mathrm{Ca}^{2+}$; caspase-3; EAA; IL-10; NF-кB; NMDA receptors
Injury to the CNS triggers an abnormal release of glutamate and other excitatory amino acids (EAAs) that contribute significantly to the neurological outcome (Wielock, 1985; Rothman and Olney, 1986). The released glutamate causes an excessive activation of glutamate receptors of the NMDA subtype, leading to an abnormal influx of $\mathrm{Ca}^{2+}$ in viable neurons (Garthwaite et al., 1986; MacDermott et al., 1986) and a subsequent neuronal death (Choi, 1988; Hahn et al., 1988). The type of cell death caused seems to depend on the nature of the injury. Necrosis occurs after an acute insult, whereas apoptotic cell death is involved in propagation of the secondary injury (Bonfoco et al., 1995; Liu et al., 1997; Yakovlev et al., 1997). Because apoptotic neurons can be rescued, because they remain viable for a period of time, compounds that prevent apoptosis may have a therapeutic significance.

The cytokine interleukin-10 (IL-10) has been shown to improve neurological outcome after CNS injury (Knoblach and Faden, 1998; Bethea et al., 1999) and to render neurons in culture less vulnerable to ischemic and EAA-mediated damage (Grilli et al., 2000). IL-10 is notoriously known as an inhibitor of the synthesis of inflammatory cytokine, including tumor necrosis factor- $\alpha$ (TNF- $\alpha$ ) and IL-1 $\beta$ (Bogdan et al., 1992; Wang et al.,

Received Oct. 9, 2000; revised Feb. 9, 2001; accepted Feb. 14, 2001.

This work was supported by grants from American Heart Association Nation's Affiliate (I.M.), Health and Human Services Grants HL 28940 (G.B.) and MH58946 and MH01680 (S.V.), and a fellowship from Schering Plough Research Institute (A.B.). We thank Randi Goodnight for her help in computer programs and image analysis and Dr. S. Narula for the gift of IL-10.

Correspondence should be addressed to Dr. Italo Mocchetti, Department of Neuroscience, Research Building, Georgetown University, 3900 Reservoir Road NW, Washington, DC 20007. E-mail: moccheti@gunet.georgetown.edu.

Copyright (C) 2001 Society for Neuroscience $0270-6474 / 01 / 213104-09 \$ 15.00 / 0$
1994; Kline et al., 1995; Di Santo et al., 1997; Bethea et al., 1999; Sawada et al., 1999). Some of these cytokines can exacerbate neuronal damage after CNS trauma (Mocchetti and Wrathall, 1995; Feuerstein et al., 1998); therefore, it has been suggested that the IL-10 ability to improve neurological outcome after CNS injury relies on its anti-inflammatory effects. However, these properties cannot fully explain why IL-10 can also reduce glutamate-mediated cell death (Grilli et al., 2000). Thus, the mechanisms underlying the neuroprotective properties of IL-10 are not fully understood.

Evidence has accumulated suggesting that neurotrophic factors, such as brain-derived neurotrophic factor (BDNF) and basic fibroblast growth factor (FGF2), prevent glutamate-mediated neuronal cell death in culture by blocking the sustained increase in cytosolic free $\mathrm{Ca}^{2+}$ concentration evoked by toxic concentrations of glutamate (Mattson et al., 1989; Cheng et al., 1995). This effect has been shown to depend on the ability of these neurotrophic factors to reduce the synthesis of specific subunits of NMDA receptors (Brandoli et al., 1998). In contrast, the proinflammatory cytokine IL-6 increases excitotoxicity by enhancing NMDA receptor function (Qiu et al., 1998). IL-10 may exert a neuroprotective effect by a mechanism similar to that of growth factors and opposite to that of IL-6. However, this hypothesis remains primarily speculative. In addition, IL-10 has been shown to slow down progression of apoptosis in immuno-derived cells (Schottelius et al., 1999). Hence, IL-10 may improve neurological outcome after CNS trauma by reducing apoptosis and, thus, secondary injury processes.

The current study was undertaken to examine the ability of IL-10 to prevent EAA-mediated neuronal cell death in cerebellar 
granule cells and gain insights into the mechanisms underlying this effect. We report that IL-10 prevents glutamate-mediated apoptotic cell death by blocking the activity of proapoptotic markers.

\section{MATERIALS AND METHODS}

\section{Cell culture}

Cerebellar granule cells were prepared from 8-d-old Sprague Dawley rat pups (Taconic Farms, Germantown, NY) as described previously (Brandoli et al., 1998; Marini et al., 1998). Briefly, neurons were plated onto poly-L-lysine $(1 \%)$ precoated $100 \mathrm{~mm}$ plastic dishes at a density of $2.5 \times$ $10^{6} \mathrm{cells} / \mathrm{ml}$ and grown in Basal Medium Eagle (Life Technologies, Gaithersburg, MD) containing glutamine (2 mM), fetal calf serum (10\%), $\mathrm{KCl}(25 \mathrm{~mm})$, gentamicin $(100 \mu \mathrm{g} / \mathrm{ml})$, and penicillin-streptomycin $(10,000 \mathrm{U} / \mathrm{ml})$. Cells were maintained at $37^{\circ} \mathrm{C}$ in $5 \% \quad \mathrm{CO}_{2}-95 \%$ air. Cytosine arabinoside $(10 \mu \mathrm{M})$ was added $24 \mathrm{hr}$ after cell plating to inhibit glial proliferation. At the time of the experiments, these cultures were composed of $\sim 95 \%$ neurons and $\sim 5 \%$ of non-neuronal cells, such as astrocytes, oligodendrocytes, and endothelial cells. Human recombinant IL-10 (a gift from Dr. S. Narula, Schering-Plough, Kenilworth, NJ), glutamate, or NMDA (Sigma, St. Louis, MO) were added to the cultures at $8 \mathrm{~d}$ in vitro. After the addition of glutamate or other compounds, cultures were kept in the same medium until analysis of cell viability. Sister cultures that received medium alone were used as a control.

\section{Cell survival}

The percent of surviving neurons in the presence of IL-10 and/or glutamate was estimated by determining the activity of mitochondrial dehydrogenases [3(4,5-dimethylthiazol-2-yl)-2.5-diphenyltetrazolium bromide (MTT) assay] and the number of apoptotic cells [in situ terminal deoxynucleotidyl transferase-mediated biotinylated UTP nick end labeling (TUNEL)].

MTT assay. The conversion of the yellow tetrazolium salt (MTT) to the purple formazan dye is dependent on the activity of mitochondrial dehydrogenases and is, therefore, reflective of the viability of the cell and the cytotoxicity of glutamate. The assay was performed according to the specifications of the manufacturer (MTT Kit I; Boehringer Mannheim, Indianapolis, IN). Briefly, neurons were cultured on 96-well plates, $10 \mu \mathrm{g}$ of the $5 \mathrm{mg} / \mathrm{ml}$ MTT labeling reagent was added to each well containing neurons in $100 \mu \mathrm{l}$ of medium, and the plate was incubated for $4 \mathrm{hr}$ in a humidified atmosphere. After the incubation, $100 \mu \mathrm{l}$ of the solubilization solution were added to each well for $18 \mathrm{hr}$. The absorbance of the samples was measured at a wavelength of 570 and $700 \mathrm{~nm}$ (reference wavelength). Unless otherwise indicated, the extent of MTT conversion in cells exposed to glutamate is expressed as a percentage of control.

In situ TUNEL. Cerebellar granule cells were plated onto $25-\mathrm{mm}$ round, 1-mm-thick glass coverslips (Fisher Scientific, Houston, TX) precoated with poly-L-lysine $(1 \%)$. Cells were washed with PBS, fixed with $4 \%$ paraformaldehyde for $30 \mathrm{~min}$, and rinsed three times with PBS. Cells were then permeabilized with $0.1 \%$ Triton $\mathrm{X}-100$ in PBS and then treated with $0.3 \% \mathrm{H}_{2} \mathrm{O}_{2}$ for 30 min to eliminate endogenous peroxidases. The DNA nick labeling reaction was performed using $50 \mathrm{U} / \mathrm{ml}$ Klenow (Boehringer Mannheim) and $2 \mathrm{mM}$ dNTP with $0.5 \mathrm{~nm}$ biotin-16-dUTP in buffer A $\left(0.05 \mathrm{M}\right.$ Tris $\mathrm{HCl}, \mathrm{pH} 5.5,5 \mathrm{~mm} \mathrm{MgCl}_{2}, 14.5 \mathrm{~mm}$ 2-mercaptoethanolsulfonic acid, and $50 \mathrm{mg} / \mathrm{ml} \mathrm{BSA}$ ) for $60 \mathrm{~min}$ at $37^{\circ} \mathrm{C}$. Cells were then rinsed in PBS and incubated with streptavidinperoxidase-HRP $(50 \mu \mathrm{g} / \mathrm{ml})$ for $30 \mathrm{~min}$ at $37^{\circ} \mathrm{C}$. After rinsing, the labeling was visualized using diaminobenzidine. The viable neurons were quantified by counting TUNEL-positive cell bodies, and results are expressed as percent of cell survival.

\section{Double labeling}

For caspase-3 and TUNEL double labeling, neurons were plated onto 12-mm-round, 1-mm-thick precoated glass coverslips. Cells were fixed with $4 \%$ paraformaldehyde, post-fixed in ethanol/acetic acid 2:1, washed, and incubated with caspase-3-p20 antibody (1:1000 dilution; Santa Cruz Biotechnology, Santa Cruz, CA). After rinsing with PBS, cells were equilibrated according to the instructions of the manufacturer (ApoTag; Intergen, Purchase, NY), incubated with TdT enzyme in the presence of digoxigenin-labeled dNTP, followed by anti-digoxigenin (fluorescein conjugate) antibody. Cells were then incubated with secondary antibody for caspase-3, Texas Red anti-goat (1:500; Vector Laboratories, Burlingame, CA) and mounted using Vectashield Mounting Medium with 4',6'-diamidino-2-phenylindole (Vector Laboratories) to detect viable cells. Reaction was visualized with the Nikon (Tokyo, Japan) inverted fluorescent microscope ECLIPSE TE300. Optronics Magnafire software (Optronics, Goleta, CA) was used to analyze positive cells.

\section{Caspase-3-like activity}

Neurons were plated onto $100 \mathrm{~mm}$ dishes. Caspase-3-like activity was measured in lysates of cerebellar granule cells using the caspase-3 colorimetric assay protease kit (Chemicon, Temecula, CA) following the instructions of manufacturer. In brief, neurons were lysed in ice-cold lysis buffer $(150 \mathrm{~mm} \mathrm{NaCl}, 20 \mathrm{~mm}$ Tris $\mathrm{HCl}, \mathrm{pH} 7.2,1 \%$ Triton $\mathrm{X}-100$, and 1 mM DTT) for 10 min. After removal of cellular debris by centrif ugation, protein levels in the lysates (cytosolic extract) were measured by the Bradford Coomassie blue colorimetric assay (Bio-Rad, Hercules, CA) and equalized accordingly to obtain $150 \mu \mathrm{g}$ of cytosolic extract per sample. Samples were incubated with $200 \mu \mathrm{M}$ caspase-3 substrate $N$-acethyl-Asp-Glu-Val-Asp (DEVD)-p-nitroanilide at $37^{\circ} \mathrm{C}$ for $2 \mathrm{hr}$. Samples were analyzed at $400 \mathrm{~nm}$ in a microtiter plate reader. Data are expressed as fold increase-decrease in caspase-3 activity compared with control cells.

\section{Fluorescence $\mathrm{Ca}^{2+}$ imaging}

Cytosolic free $\mathrm{Ca}^{2+}$ concentration $\left(\left[\mathrm{Ca}^{2+}\right]_{\mathrm{i}}\right.$ ) was measured by single-cell fura-2 fluorescence ratio imaging as described previously (De Bernardi et al., 1996). For this purpose, neurons were plated onto 25 -mm-round, 1-mm-thick glass coverslips (Fisher Scientific) precoated with poly-Llysine $(1 \%)$. For the acute $(10 \mathrm{~min})$ treatment, cells were labeled with fura-2 (fura-2 AM; Molecular Probes, Eugene, OR) in growth medium for $30 \mathrm{~min}$ at $37^{\circ} \mathrm{C}$ in an atmosphere of $5 \% \mathrm{CO}_{2}$, washed in $\mathrm{Mg}^{2+}$-free Locke's solution (in mM: $154 \mathrm{NaCl}, 5.6 \mathrm{KCl}, 3.6 \mathrm{NaHCO}_{3}, 2.3 \mathrm{CaCl}_{2}, 5.6$ glucose, and 15 HEPES, pH 7.4) and imaged. Resting $\left[\mathrm{Ca}^{2+}\right]_{\mathrm{i}}$ was recorded for $\sim 60 \mathrm{sec}$, vehicle (medium alone) or IL-10 $(50 \mathrm{ng} / \mathrm{ml})$ was added, and $\left[\mathrm{Ca}^{2+}\right]_{\mathrm{i}}$ was followed for $10 \mathrm{~min}$. Cells were then exposed to NMDA $(50 \mu \mathrm{M})$, and $\left[\mathrm{Ca}^{2+}\right]_{\mathrm{i}}$ was monitored over a 20-30 min period. For the $24 \mathrm{hr}$ treatment, neurons were incubated with growth medium or IL-10 $(50 \mathrm{ng} / \mathrm{ml})$ for $24 \mathrm{hr}$. Cells were then labeled with fura-2, imaged and challenged with NMDA as described above. $\mathrm{Ca}^{2+}$ imaging was performed at room temperature using an Attofluor RatioVision digital fluorescence microscopy system (Atto Instruments, Rockville, MD) equipped with a Zeiss Axiovert 135 microscope and a F-Fluar $40 \times, 1.3$ numerical aperture oil-immersion objective, as described previously (De Bernardi et al., 1996). Briefly, fura-2 was excited at 334 and $380 \mathrm{~nm}$ with its emission monitored at $510-530 \mathrm{~nm}$; the $334 / 380 \mathrm{~nm}$ excitation ratio increases as a function of the $\left[\mathrm{Ca}^{2+}\right]_{\mathrm{i}}$. Before the experiments, the instrument was calibrated (calibration was done in vitro with fura-2 pentapotassium salt in the presence of high concentration of $\mathrm{Ca}^{2+}$ or EGTA), and the $334 / 380 \mathrm{~nm}$ excitation ratio was converted to $\left[\mathrm{Ca}^{2+}\right]_{\mathrm{i}} \mathrm{nM}$ values (Grynkiewicz et al., 1985). For each coverslip, 50-99 neurons were simultaneously imaged in a given microscopic field, and single-cell $\mathrm{Ca}^{2+}$ responses were collected and averaged to yield $\left[\mathrm{Ca}^{2+}\right]_{\mathrm{i}}$ population means \pm SEM) that were plotted versus time.

\section{Electrophysiology}

Electrodes were pulled from thin-walled borosilicate glass (Drummond Scientific, Broomall, PA) using a Narashige (Tokyo, Japan) PP-83 vertical puller. Electrodes had open-tip resistances of 5-8 $\mathrm{M} \Omega$. Recordings were made on the stage of a CK2 inverted phase-contrast microscope (Olympus Optical, Lake Success, NY) at room temperature $\left(22-25^{\circ} \mathrm{C}\right)$. Cultured granule cells were voltage clamped at $-60 \mathrm{mV}$ in the whole-cell configuration using the patch-clamp technique after series resistance compensation (typically 15-20 M $\Omega$ ). Series resistance was monitored for constancy, and cell capacitance was estimated from the average of 10 transient relaxation currents produced by $5 \mathrm{mV}$ hyperpolarizing voltage pulses. The recording pipette contained (in $\mathrm{mM}$ ): $145 \mathrm{~K}$-gluconate, 5 EGTA, 5 MgATP, $0.2 \mathrm{NaGTP}$, and $10 \mathrm{~mm}$ HEPES at pH 7.2 with $\mathrm{KOH}$. Cells were bathed in $145 \mathrm{~mm} \mathrm{NaCl}, 5 \mathrm{~mm} \mathrm{KCl}, 1 \mathrm{~mm} \mathrm{CaCl}, 5 \mathrm{~mm}$ glucose, $5 \mathrm{~mm}$ HEPES, and $20 \mu \mathrm{M}$ glycine at $\mathrm{pH}$ 7.4. Osmolarity was adjusted to $325 \mathrm{mOsm}$ with sucrose. The culture dish in the recording chamber $(<500 \mu$ l total volume) was continuously perfused $(5 \mathrm{ml} / \mathrm{min})$ to prevent accumulation of drugs.

Drug application. All of the drugs were diluted in bath solution. NMDA $(200 \mu \mathrm{M})$ was applied directly by a gravity-fed Y-tubing delivery system (Murase et al., 1989) placed within $100 \mu \mathrm{m}$ of the recorded cell. Drug application had fast onset $(<10 \mathrm{msec})$ and achieved a completely local perfusion of the recorded cell. Ifenprodil (Reseach Biochemicals, 
Natick, MA) or IL-10 were coapplied with NMDA after at least 1 min of preperfusion. The response recovery was achieved after 5-7 min of wash from the last application. Recordings were performed in the presence of $\mathrm{GABA}_{\mathrm{A}}$ and AMPA receptor antagonists bicuculline methiodide (10 $\mu \mathrm{M}$; Sigma) and $5 \mu \mathrm{M}$ 6-nitro-7-sulfamoilbenzo[f]quinoxaline-2,3-dione (Tocris Coockson, St. Louis, MO), diluted in bath solution from stock solutions prepared in water and DMSO, respectively.

Data acquisition and analysis. Currents were monitored with a patch amplifier (EPC-7; List Electronics, Darmstadt, Germany), filtered at 1.5 $\mathrm{kHz}$ (eight-pole low-pass Bessel; Frequency Devices, Haverhill, MA), and digitized using a IBM-compatible microcomputer equipped with the Digidata 1200 data acquisition board and pClamp 8 software (Axon Instruments, Foster City, CA). Off-line data analysis, dose-response fitting, and figure preparation were performed with Origin (MicroCal Software, Northampton, MA) and pClamp 8 software (Axon Instruments). Data values are expressed as mean \pm SEM. Significance was assessed with ANOVA followed by independent $t$ tests, unless otherwise indicated.

\section{Electrophoretic mobility shift assay}

Nuclear factor $\kappa \mathrm{B}(\mathrm{NF}-\mathrm{kB})$ binding activity was analyzed in nuclear extracts from cerebellar granule cells prepared as described previously (Colangelo et al., 1998). Nuclei were incubated with a double-stranded oligonucleotide containing a consensus NF-kB binding site (5'GGCAGAGGGGACTTTCCGAGAGGC-3') labeled with ${ }^{32} \mathrm{P}-\mathrm{dCTP}$ by Klenow polymerase (Boehringer Mannheim). Binding reactions were performed for $20 \mathrm{~min}$ at room temperature in a $25 \mu \mathrm{l}$ of reaction containing $10 \mathrm{~mm}$ HEPES, pH 7.6, $134 \mathrm{~mm} \mathrm{NaCl}$, 4\% (w/v) Ficoll, 5\% (v/v) glycerol, $1 \mathrm{~mm}$ EDTA, $10 \mathrm{~mm}$ DTT, $0.25 \mu \mathrm{g}$ of BSA, $0.06 \%$ bromophenol blue, $1 \mu \mathrm{g}$ poly (dI-dC), and $0.5 \mathrm{ng}$ of probe. Protein:DNA complexes were separated on 6\% PAGE. For supershift assays, nuclear extracts were preincubated with $1 \mu \mathrm{l}$ of antisera at $4^{\circ} \mathrm{C}$ for $20 \mathrm{~min}$ before addition of the probe. Quantitation of binding activity was done by densitometry as described previously (Colangelo et al., 1998).

\section{RESULTS}

\section{IL-10 prevents glutamate-mediated cell death}

Before examining whether IL-10 limits glutamate excitotoxicity, we first established time- and dose-dependent excitotoxicity in cerebellar granule cells exposed continuously to glutamate. Thus, cultures were exposed to medium alone or containing increasing concentrations of glutamate for various times without replacing the medium. Cell death-survival was measured by MTT assay. Glutamate $(300 \mu \mathrm{M})$ induced a time-dependent decrease in cell viability starting at $6 \mathrm{hr}$ and culminating at $24 \mathrm{hr}$ (Fig. 1A). Glutamate-mediated excitotoxicity was blocked by the NMDA receptor antagonist (+)-5-methyl-10,11-dihydro-5H-dibenzo [a,d] cyclohepten-5,10-imine maleate (MK-801) (Fig. 1A), supporting previous findings that glutamate toxicity depends on stimulation of NMDA receptors (Schramm et al., 1990; Marini et al., 1997). Glutamate also evoked a dose-dependent excitotoxic effect starting from a concentration of $100 \mu \mathrm{M}$ and peaking at $500 \mu \mathrm{M}$ (Fig. $1 B)$. Neurons were then exposed to IL-10 $(50 \mathrm{ng} / \mathrm{ml})$ for $14 \mathrm{hr}$ before the addition of glutamate, and cell survival was measured $14 \mathrm{hr}$ later. IL-10 prevented glutamate-mediated cell death even when glutamate was used at the highest concentration (Fig. 1B).

\section{IL-10 inhibits glutamate-mediated apoptosis}

In cerebellar granule cells, glutamate evokes necrosis and/or apoptosis depending on the experimental conditions used (Resink et al., 1994; Ankarcrona et al., 1995; Du et al., 1997). Thus, we determine whether IL-10 prevented glutamate-mediated apoptosis by in situ TUNEL (Fig. 2). In control neurons, few cells (at the most 5\%) were TUNEL-positive (Fig. $2 A$ ). Exposure of cells to glutamate for $24 \mathrm{hr}$ increased the number of TUNEL-positive cells (Fig. 2B). Pretreatment of neurons with IL-10 for $24 \mathrm{hr}$, a treatment that per se did not alter cell viability (Fig. $2 C$ ), blocked glutamate-mediated increase in TUNEL-positive cells (Fig. 2D).
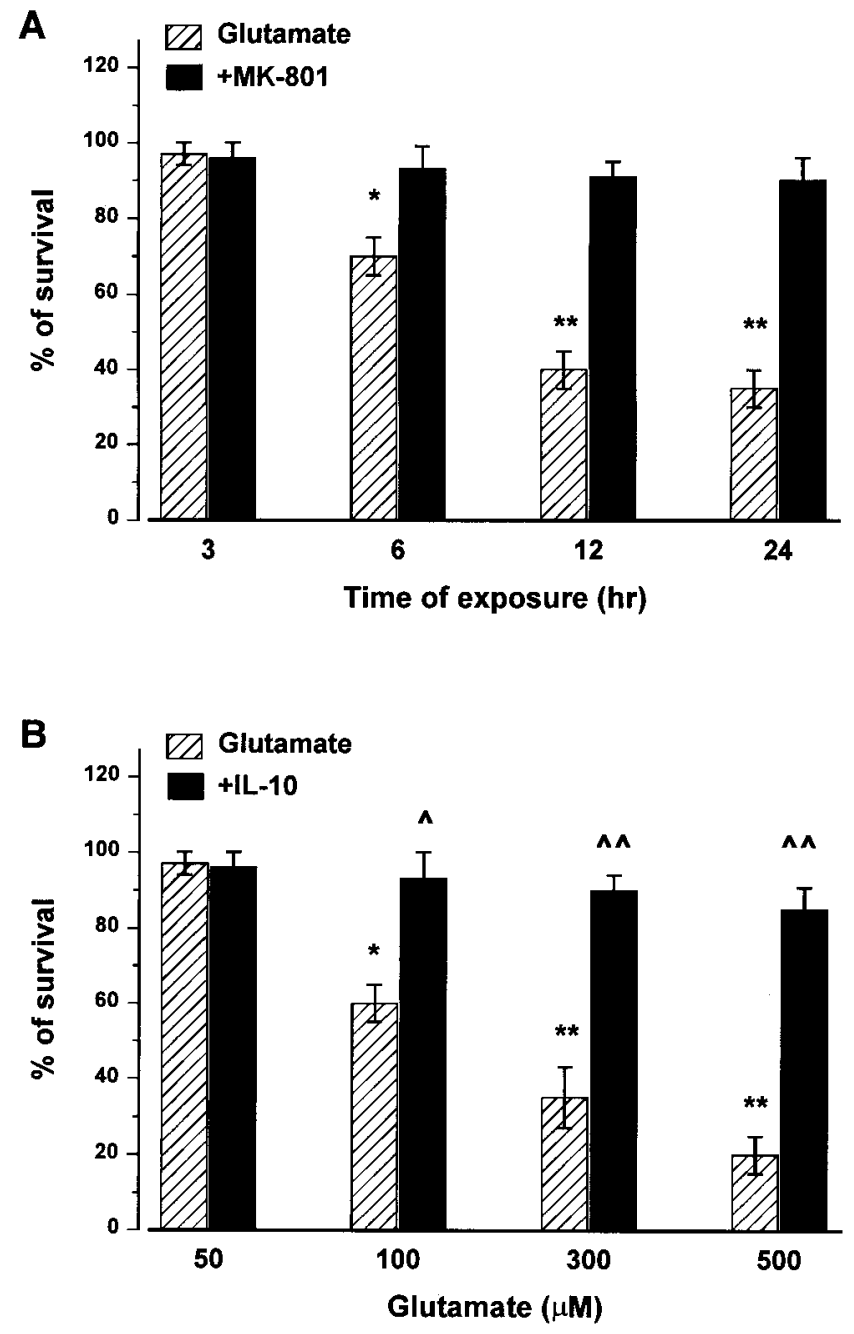

Figure 1. Glutamate induces a time- and dose-dependent excitotoxicity blocked by IL-10. $A$, Cerebellar granule cells were exposed to glutamate $(300 \mu \mathrm{M})$ in the presence or absence of MK-801 $(10 \mu \mathrm{M})$ for the indicated times, and then cell viability was measured at the indicated times by MTT assay. $B$, Neurons were exposed to IL-10 $(50 \mathrm{ng} / \mathrm{ml})$ for $14 \mathrm{hr}$ before the addition of different concentrations of glutamate. Cell viability was measured by MTT assay $14 \mathrm{hr}$ after glutamate addition. Data, expressed as percentage of control, are the mean \pm SEM of four separate experiments. ${ }^{*} p<0.01,{ }^{* *} p<0.005$ versus control; $\wedge p<0.01$, $\wedge \wedge p<0.005$ versus glutamate (ANOVA and Dunnett's test).

To confirm that, in our experimental condition glutamate evokes cell death by apoptosis, caspase-3 staining and in situ TUNEL were performed in the same cells. Caspase- 3 is a protease that plays a role in the EAA-mediated apoptosis in cerebellar granule cells (Du et al., 1997; Tenneti and Lipton, 2000). Figure 3 shows that all TUNEL-positive cells were also caspase-3-positive, suggesting that, in our experimental conditions, apoptosis could be the main cause of cell death by glutamate.

\section{IL-10 prevents NMDA-mediated cell death}

Cell death of cerebellar granule neurons is attributable to the overactivation of the NMDA subtype of receptors (Schramm et al., 1990; Marini et al., 1997). We then examined whether IL-10 prevented glutamate and NMDA-mediated cell death by TUNEL (Fig. 4A) and MTT (Fig. 4B) assays. Exposure of cerebellar granule cells to IL-10 for $24 \mathrm{hr}$ elicited a dosedependent neuronal protection against both EAAs (Fig. 4). In- 

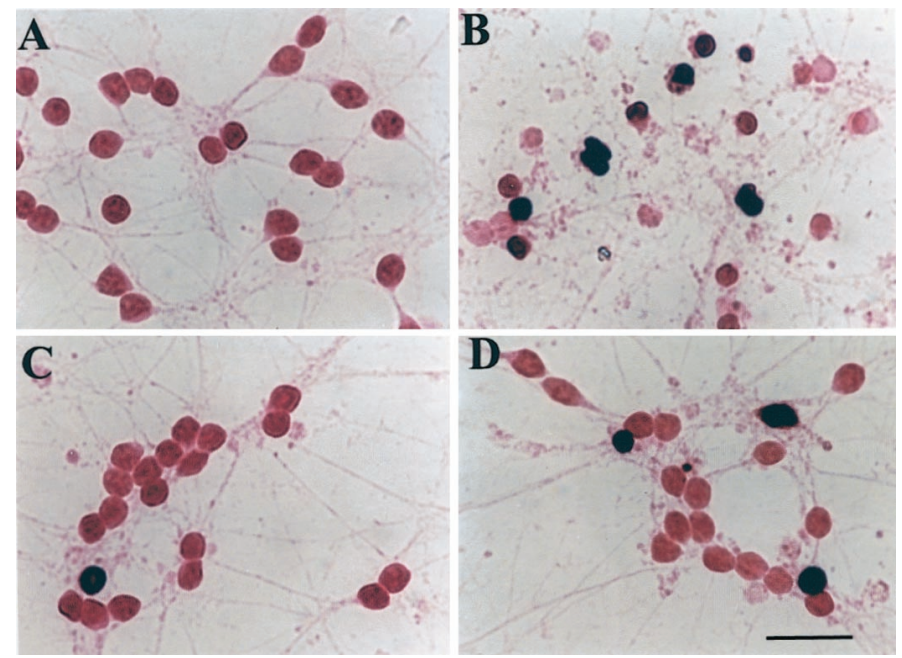

Figure 2. IL-10 reduces the increase of TUNEL-positive cells glutamate mediated. Cerebellar granule cells were exposed to medium alone $(A)$, glutamate $(B ; 300 \mu \mathrm{M})$, or IL-10 $(C ; 50 \mathrm{ng} / \mathrm{ml})$ for $14 \mathrm{hr}$, or IL-10 for 14 $\mathrm{hr}$ followed by glutamate for $14 \mathrm{hr}(D)$. Cells were then fixed and stained for TUNEL for the determination of apoptosis. In both control and IL-10-treated cultures, 95\% of cells were TUNEL-negative, whereas $\sim 65 \%$ of neurons after glutamate treatment were TUNEL-positive (dark brown). Scale bar, $15 \mu \mathrm{m}$.

deed, a significant effect of IL-10 was seen already at a concentration of $10 \mathrm{ng} / \mathrm{ml}(\sim 70 \%$ survival $)$, whereas the maximal neuroprotection ( $95 \%$ of survival) was obtained with a concentration of $50 \mathrm{ng} / \mathrm{ml}$ (Fig. 4). Similar neuroprotection was observed when neurons were exposed to MK-801 (1 $\mu \mathrm{M}) 30 \mathrm{~min}$ before glutamate (data not shown).

To establish the temporal profile of IL-10 neuroprotective effect, neurons were exposed to IL-10 $(50 \mathrm{ng} / \mathrm{ml})$ for various times $(6,12$, and $24 \mathrm{hr})$ before glutamate. In addition, to examine the effect of an acute exposure to IL-10, neurons were incubated with glutamate either concomitantly with IL-10 or $1 \mathrm{hr}$ before IL-10. Cell death was then measured by both MTT and TUNEL assays $14 \mathrm{hr}$ later. IL-10 evoked a time-dependent neuroprotection that was maximal when IL-10 was added several hours before glutamate (Fig. 5). When IL-10 was added concomitantly or after glutamate, a modest but significant neuroprotective effect was still observed (Fig. 5). These data suggest that IL-10 is an effective neuroprotective agent against glutamate-mediated cell death.

\section{Effect of IL-10 on NMDA receptor channel}

The effect of IL-10 in preventing glutamate and NMDA toxicity is rapid because it occurs even if the addition of IL-10 is delayed after glutamate. These data suggest that IL-10 may interact directly with the NMDA receptor. To test this hypothesis, we examined whether IL-10 alters NMDA currents. Cerebellar granule cells in culture were voltage clamped at $-60 \mathrm{mV}$ using whole-cell recordings with a potassium gluconate-based solution. On average, the current recorded from granule cells normalized by the cell capacitance was $25 \pm 7.3 \mathrm{pA} / \mathrm{pF}(n=65)$. NMDA applications produced desensitizing whole-cell currents (Fig. 6A). Coapplication of IL-10 (50 ng/ml) with NMDA did not change the NMDA response (Fig. $6 A$ ). The ratio of the maximal current densities recorded in each cell in the presence or the absence of IL-10 (50 ng/ml) revealed that the current density did not change in cells exposed concomitantly to IL-10 and NMDA (Fig. 6B, first bar) or preexposed to IL-10 for $30 \mathrm{~min}, 180 \mathrm{~min}$, or $14 \mathrm{hr}$ before NMDA (Fig. 6B).

Because some neuroprotective neurotrophic factors have been shown to alter the synthesis of NMDA receptor subunits (Brandoli et al., 1998), NMDA currents were also studied in the presence of Ifenprodil, a selective antagonist of NMDA receptor that include the NR1 and NR2B subunits (Williams, 1993). Similar to a previous report (Corsi et al., 1998), $10 \mu \mathrm{M}$ Ifenprodil reduced the peak currents elicited by $200 \mu \mathrm{M}$ NMDA by $50 \pm$ $16 \%$. In 12 granule cells from three distinct experiments, IL-10 $(50 \mathrm{ng} / \mathrm{ml})$ incubation did not alter the Ifenprodil effect, which was $49 \pm 11 \%$ after $30 \mathrm{~min}$ of IL-10 treatment, $52 \pm 19 \%$ after 180 min of treatment, and $48 \pm 18 \%$ for the overnight treatments. These results indicate that IL-10 treatment failed to alter the functional expression of distinct subunits of NMDA receptor in cerebellar granule cells.

\section{IL-10 does not prevent EAA-evoked $\left[\mathrm{Ca}^{2+}\right]_{\mathrm{i}}$ increase}

The relatively rapid effect of IL-10 in preventing glutamate and NMDA toxicity suggests that IL-10 might interact directly with the NMDA receptor. Because activation of NMDA receptor promotes influx of extracellular $\mathrm{Ca}^{2+}$ through its own channel, the functional state of the NMDA receptor can be assessed by measuring its ability to evoke an $\left[\mathrm{Ca}^{2+}\right]_{i}$ increase after stimula-
TUNEL
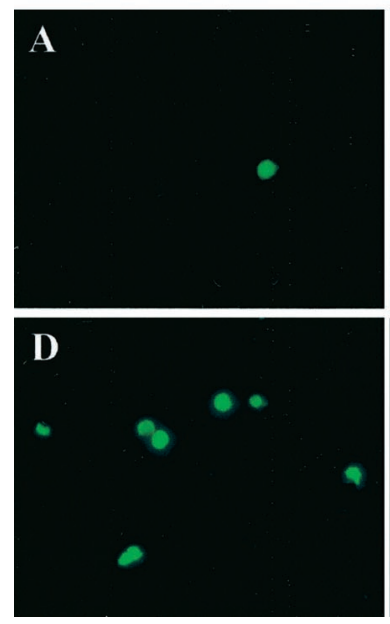

caspase-3 p20
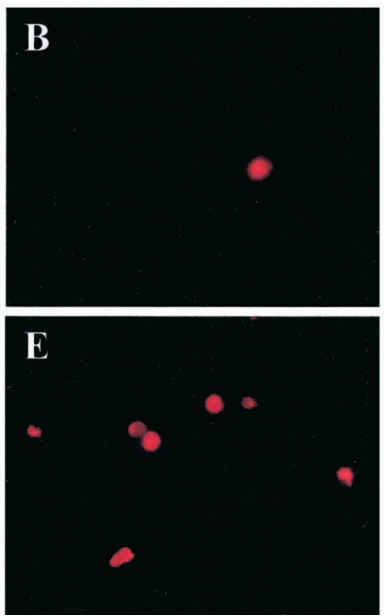

overlay
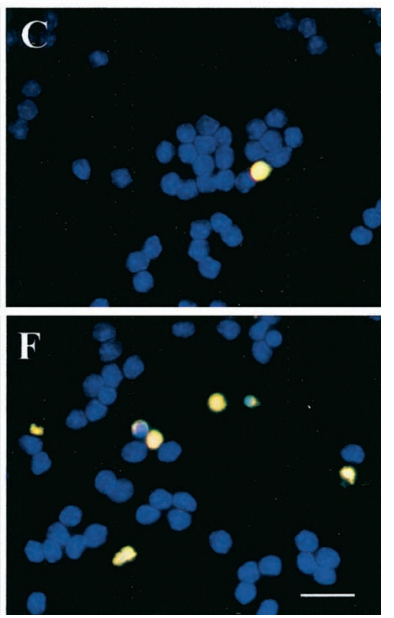

Figure 3. Caspase-3 immunoreactivity in TUNELpositive cells. Neurons were exposed to medium alone or glutamate $(300 \mu \mathrm{M})$ for $3 \mathrm{hr}$. Determination of apoptotic neurons was performed by TUNEL $(A, D)$ and caspase-3-p20 $(B, E)$ staining. $A-C$, Control cells; $D-F$, glutamate-treated cells. Analysis by Magnafire revealed that all TUNEL-positive cells were also positive for caspase-3 (overlay). Scale bar, $15 \mu \mathrm{m}$. 

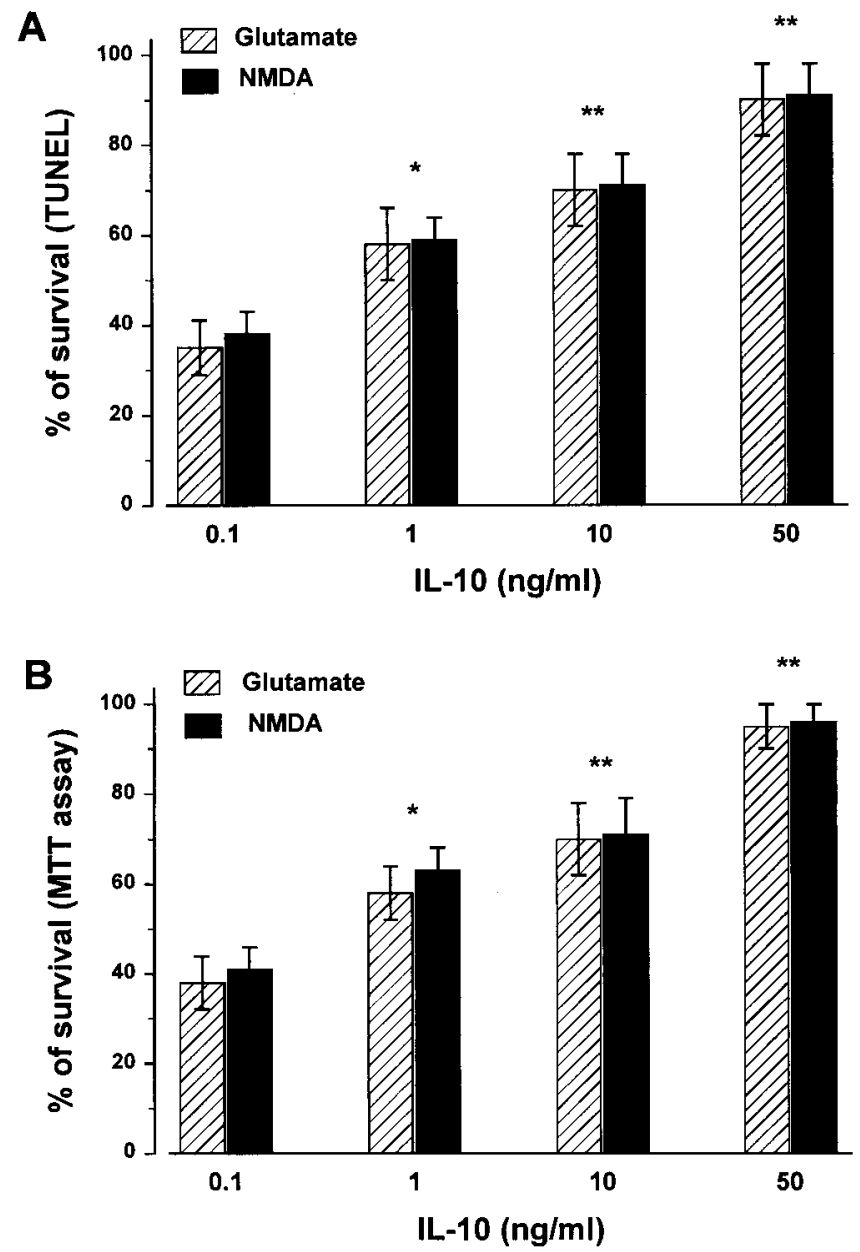

Figure 4. The neuroprotective effect of IL-10 is dose-dependent. Cerebellar granule cells were exposed to different concentrations of IL-10 for $14 \mathrm{hr}$, and then glutamate or NMDA (300 $\mu \mathrm{M}$ each) was added for additional $14 \mathrm{hr}$. Cell survival was determined by in situ TUNEL $(A)$ and MTT $(B)$ assay. Data, expressed as percentage of control, are the mean \pm SEM of four separate experiments $\left(n=12\right.$ each group). ${ }^{*} p<0.01,{ }^{* *} p<$ 0.005 versus glutamate or NMDA alone (ANOVA and Dunnett's test).

tion with a proper ligand. Thus, we investigated whether IL-10 blocks glutamate- or NMDA-mediated surge in $\left[\mathrm{Ca}^{2+}\right]_{\mathrm{i}}$. Cerebellar granule cells were exposed to either vehicle or IL-10 (50 $\mathrm{ng} / \mathrm{ml})$ for $10 \mathrm{~min}$ or $24 \mathrm{hr}$, NMDA $(50 \mu \mathrm{M})$ was then added, and $\left[\mathrm{Ca}^{2+}\right]_{\mathrm{i}}$ was measured over time. Exposure of neurons to IL-10 did not affect $\left[\mathrm{Ca}^{2+}\right]_{\mathrm{i}}$, and the resting $\left[\mathrm{Ca}^{2+}\right]_{\mathrm{i}}$ monitored before the addition of NMDA showed no statistically significant differences between neurons treated with vehicle or IL-10 for either 10 min or $24 \mathrm{hr}$ (in nM: vehicle-treated, $40 \pm 8.6, n=10$; IL-10treated, $52 \pm 7.8, n=10)$. $\left[\mathrm{Ca}^{2+}\right]_{\mathrm{i}}$ increase induced by NMDA peaked within $10 \mathrm{~min}$ from EAA addition and remained elevated for at least $20 \mathrm{~min}$. The $\left[\mathrm{Ca}^{2+}\right]_{\mathrm{i}}$ rise evoked by NMDA in neurons pretreated with IL-10 for $10 \mathrm{~min}$ or $24 \mathrm{hr}$ (the latter treatment maximally preventing excitotoxicity) was comparable, in both magnitude and kinetics, with that elicited in control, vehicletreated cells (Fig. 7A,B). The magnitude of the EAA-evoked $\mathrm{Ca}^{2+}$ response varied among the four cerebellar granule neuron preparations used in this study, regardless of the pretreatment (vehicle or IL-10, $10 \mathrm{~min}$ or $24 \mathrm{hr}$ ). Peak $\left[\mathrm{Ca}^{2+}\right]_{\mathrm{i}}$ increase (expressed as fold above basal) was as follows: NMDA-treated cells, $10.7 \pm 3.6, n=6$; IL-10 plus NMDA-treated cells, $12.5 \pm 5.6, n=$

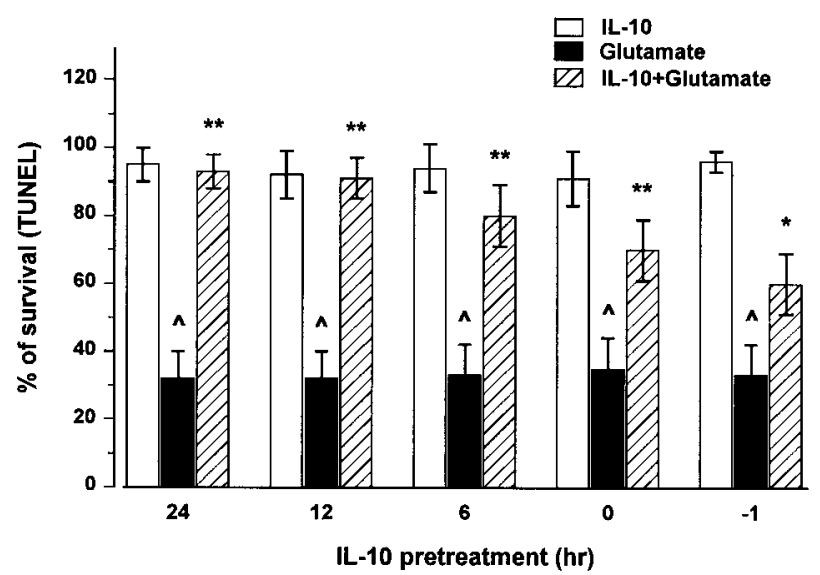

Figure 5. IL-10 elicits a time-dependent neuroprotection against glutamate. Neurons were exposed to IL-10 alone $(50 \mathrm{ng} / \mathrm{ml})$ for 6,12 , and 24 $\mathrm{hr}$ before glutamate, to IL-10 and glutamate simultaneously ( 0 ), or to glutamate $1 \mathrm{hr}$ before IL-10 (-1). Cell survival was measured $14 \mathrm{hr}$ after glutamate by TUNEL assay. Data are the mean \pm SEM of three independent experiments $\left(n=15\right.$ each group). ${ }^{\wedge} p<0.005$ versus control; ${ }^{*} p<0.05,{ }^{*} p<0.005$ versus glutamate (ANOVA and Dunnett's test).

6. These results show that IL-10 does not prevent the EAAmediated increase in $\left[\mathrm{Ca}^{2+}\right]_{\mathrm{i}}$ through NMDA receptor channels.

\section{IL-10 prevents the increase in NF- $\mathrm{B}$ binding activity evoked by glutamate}

One way to prevent EAA-mediated apoptosis is to block the activity of proapoptotic proteins. The transcription factor NF- $\kappa \mathrm{B}$ is associated with differentiation and apoptosis (O'Neill and Kaltschmidt, 1997). In neurons, induction of NF- $\kappa$ B DNA binding by glutamate is believed to play a role in programmed neuronal cell death (Kaltschmidt et al., 1995; Grilli et al., 1996). Thus, we examined whether IL-10 affected NF- $\kappa$ B nuclear activity in cerebellar granule cells. Electrophoretic mobility shift assay (EMSA) of nuclear extracts of cells exposed for $1 \mathrm{hr}$ to glutamate $(300 \mu \mathrm{M})$ showed higher NF- $\kappa \mathrm{B}$ binding activity than control cells (Fig. $8 A$ ). Supershift experiments with specific antibodies (Fig. 8A) indicated that the active complex consisted of the typical heterodimer of $\mathrm{NF}-\kappa \mathrm{B}$ p52 and p65 found in mammalian cells (Baeuerle and Baltimore, 1996). The effect of glutamate began at $30 \mathrm{~min}$ and lasted for at least up to $3 \mathrm{hr}$ (Fig. 8B). We then examined whether IL-10, added immediately before (10 $\mathrm{min})$ glutamate, could affect the glutamate-mediated increase in NF- $\kappa \mathrm{B}$ DNA binding activity. IL-10, which per se decreased NF- $\mathrm{B}$ DNA binding activity slightly below control levels (Fig. $8 A$ ), blocked the glutamatemediated increase in NF- $\kappa \mathrm{B}$ binding activity tested at $30 \mathrm{~min}, 1 \mathrm{hr}$, and $3 \mathrm{hr}$ after EAA application (Fig. 8B).

\section{IL-10 and caspase-3-like activity}

The inhibition of $\mathrm{NF}-\kappa \mathrm{B}$ activity is very often associated with inactivation of caspases (O'Neill and Kaltschmidt, 1997), proteases that participate in the pathogenesis of CNS disorders associated with apoptosis. Several lines of independent investigations have demonstrated that, in cerebellar granule cells, caspase- 3 but not caspase- 1 plays a role in the NMDA-mediated apoptosis (Du et al., 1997; Tenneti and Lipton, 2000). In addition, we have shown that TUNEL-positive cells are also caspase-3positive (Fig. 3). Thus, we evaluated whether the neuroprotective properties of IL-10 might involve an inhibition of caspase-3-like activity. To provide quantitative data, caspase- 3 was measured by a colorimetric assay. Exposure of cerebellar granule cells to gluta- 


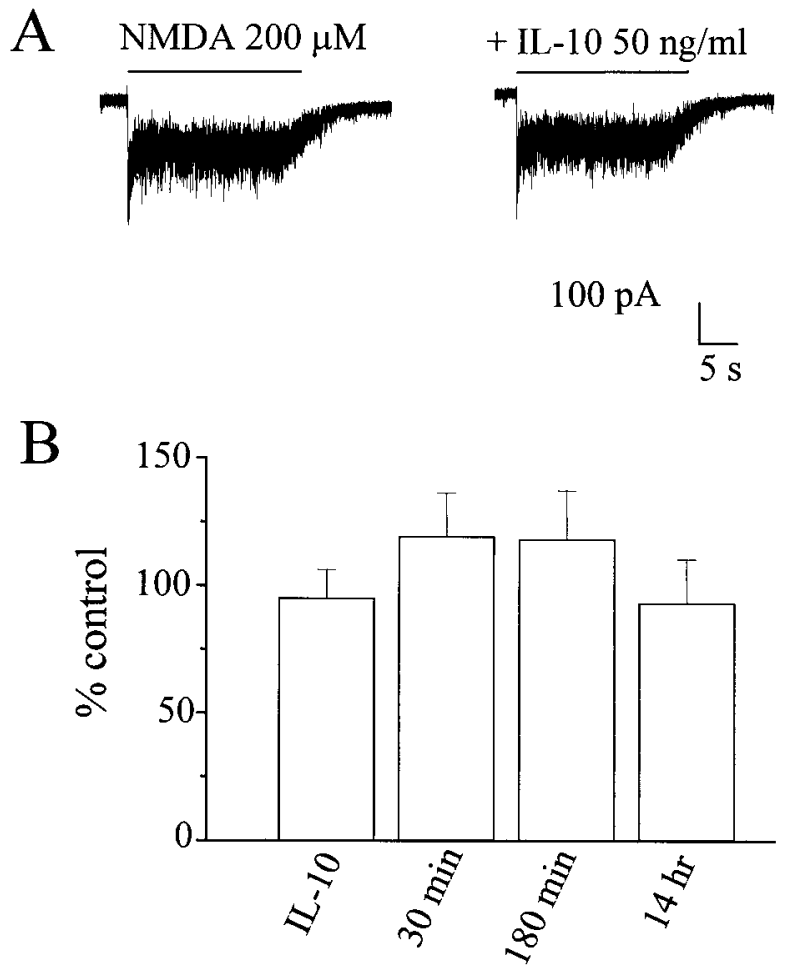

Figure 6. IL-10 fails to inhibit NMDA-activated currents. $A$, Current traces from cerebellar granule cells elicited by $200 \mu \mathrm{M}$ NMDA in the presence and absence of IL-10 (50 ng/ml). NMDA was applied by a Y-tubing device for the duration indicated by the bars. Holding potential, $-60 \mathrm{mV}$. B, Summary of the action of IL-10 treatments in cerebellar granule cells. The left histogram bar labeled $I L-10$ represents the percentage control of peak currents normalized to the cell capacitance recorded from 31 individual cells during application of NMDA in the presence of IL-10 $(50 \mathrm{ng} / \mathrm{ml})$. The other histogram bars represent the percentage control peak current density from at least 10 distinct granule neurons in three distinct sets of experiments in which cells were pretreated with IL-10 $(50 \mathrm{ng} / \mathrm{ml})$ for $30 \mathrm{~min}, 180 \mathrm{~min}$, or $14 \mathrm{hr}$. Each point represents the mean \pm SEM of the ratios of normalized current. No significant differences were found between control and treated cells.

mate $(300 \mu \mathrm{M})$ evoked an increase in caspase-3-like activity within $1 \mathrm{hr}$ (Fig. 9), an effect that lasted at least up to $3 \mathrm{hr}$ (data not shown). In lysates of cells exposed to IL-10 for $1 \mathrm{hr}$, the basal levels of caspase-3-like activity were reduced (Fig. 9). This effect was similar to that obtained with the relatively specific, irreversible caspase-3-like protease inhibitor acetyl-DEVD-chloromethylketone (DEVDK) (Fig. 9). Most importantly, IL-10, similar to DEVDK, blocked the glutamate-mediated rise in caspase-3-like activity (Fig. 9), suggesting that IL-10 may be an effective caspase-3 inhibitor.

To further examine the role of caspase- 3 in the glutamatemediated cell death, cells were incubated with IL-10 or DEVDK $(100 \mu \mathrm{M}) 10 \mathrm{~min}$ before glutamate $(300 \mu \mathrm{M})$, and cell death was measured $14 \mathrm{hr}$ later. Both compounds blocked the glutamatemediated neuronal cell death (Fig. 10), further suggesting that in these neurons excitotoxicity involves a caspase-mediated pathway.

\section{DISCUSSION}

The anti-inflammatory cytokine IL-10 has been shown to reduce vulnerability of neurons to CNS ischemia and trauma (Knoblach and Faden, 1998; Bethea et al., 1999; Grilli et al., 2000). However, the mechanisms underlying its neuroprotective activity remain to be fully elucidated. In these studies, we demonstrated that IL-10
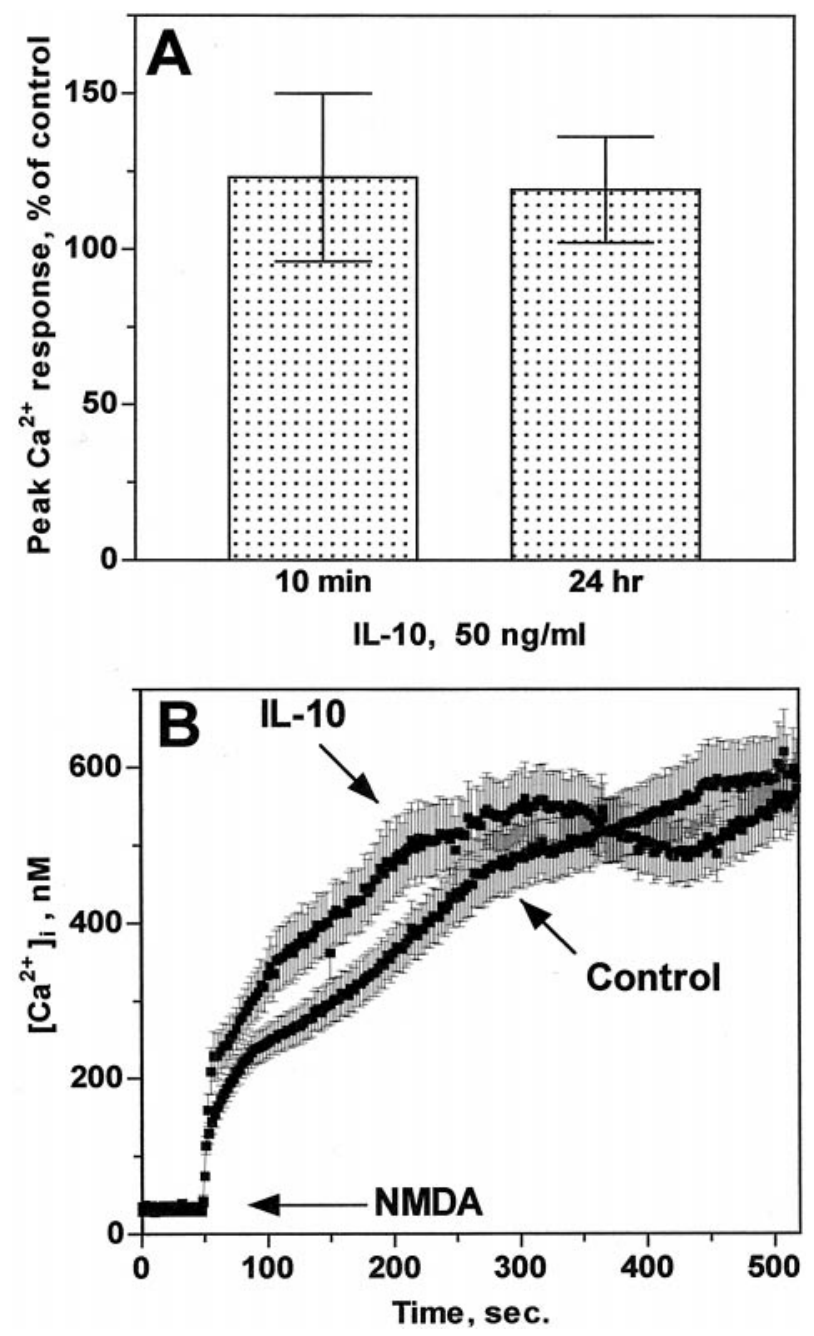

Figure 7. IL-10 fails to block EAA-mediated $\left[\mathrm{Ca}^{2+}\right]_{\mathrm{i}}$ increase. $\mathrm{Ca}^{2+}$ imaging in cerebellar granule neurons from four independent preparations was performed as described in Materials and Methods. $A$, Peak $\left[\mathrm{Ca}^{2+}\right]_{\mathrm{i}}$ increase evoked by NMDA in IL-10-treated cells and expressed as percentage of the $\mathrm{Ca}^{2+}$ response in vehicle-treated (control) cells that were imaged in parallel experiments. Data represent mean $\pm \operatorname{SEM}(n=$ 5) for both $10 \mathrm{~min}$ and $24 \mathrm{hr}(n=1$ coverslip with 50-99 neurons being imaged simultaneously). $B, \mathrm{Ca}^{2+}$ traces representative of NMDA-evoked $\left[\mathrm{Ca}^{2+}\right]_{\mathrm{i}}$ increase in neurons pretreated for $24 \mathrm{hr}$ with either vehicle (control) or IL-10. Data (mean \pm SEM) represent the $\left[\mathrm{Ca}^{2+}\right]_{\mathrm{i}}$ population mean from 96 (control) and 99 (IL-10) neurons imaged simultaneously.

prevents glutamate and NMDA-mediated cell death in primary cultures of cerebellar granule cells by blocking apoptosis. Remarkably, IL-10 prevents EAA-mediated apoptotic cell death, even when added after glutamate. Apoptosis is an event that plays an important pathophysiological role in CNS after trauma, stroke, or ischemia. In fact, apoptosis has been demonstrated to contribute to neuronal or glial cell death occurring several hours after brain or spinal cord injury (Hara et al., 1997; Liu et al., 1997; Yakovlev et al., 1997). Moreover, several lines of independent investigations have shown that apoptosis may be the major form of cell death following EAA accumulating after an insult to the CNS (for review, see Bettmann and Henderson, 1998). Thus, the ability of IL-10 to reduce EAA-mediated apoptosis could explain the therapeutic efficacy of this cytokine and shed some insights into the mechanisms whereby IL-10 reduces infarct volume after middle cerebral artery occlusion (Spera et al., 1998; Grilli et al., 
$\mathbf{A}$
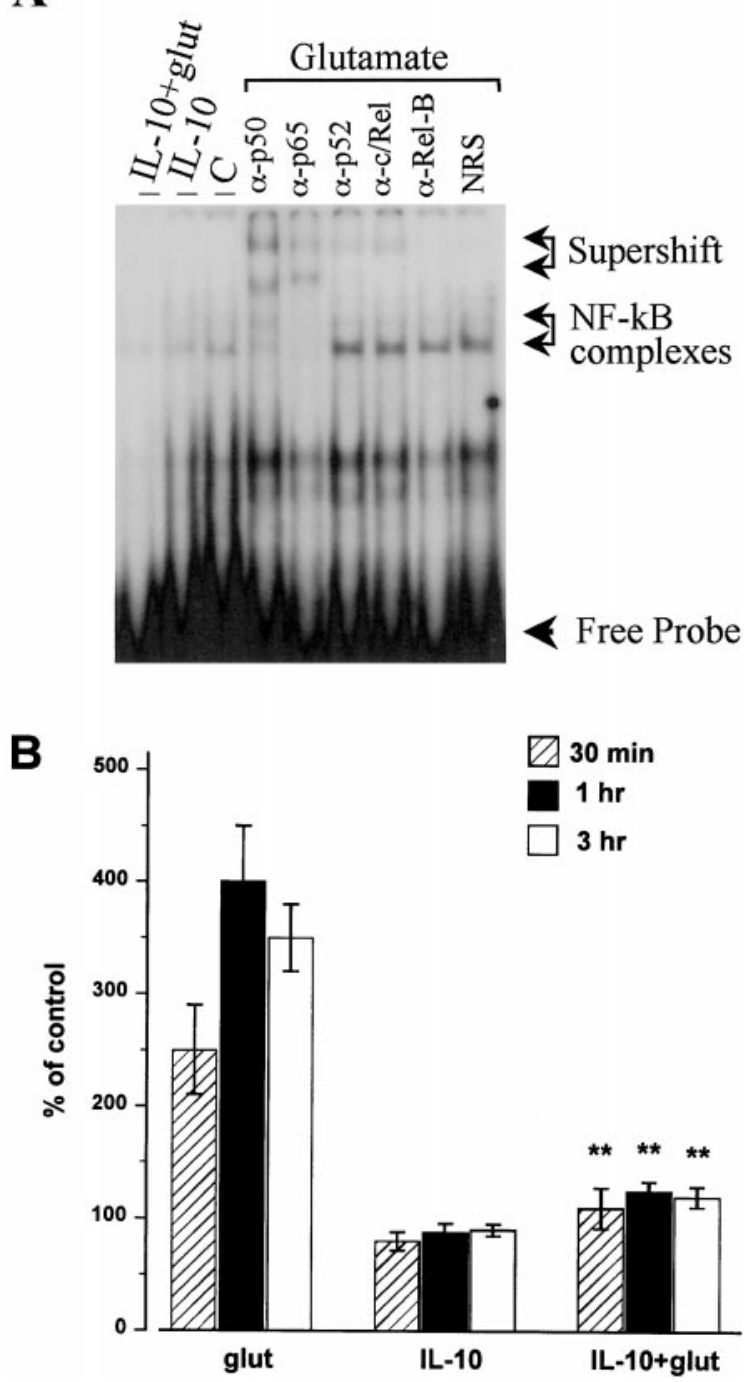

Figure 8. IL-10 blocks the glutamate-mediated increase in NF-kB binding activity. Cells were exposed to glutamate $(300 \mu \mathrm{M})$, IL-10 $(50 \mathrm{ng} / \mathrm{ml})$, or a combination of glutamate and IL-10 for various times, nuclear extracts were prepared, and then NF-kB binding activity was measured by EMSA. $A$, Typical EMSA showing NF- $\kappa \mathrm{B}$ complexes (arrows). These complexes were supershifted by $\alpha$-p50 and p65 but not p52 and c/Rel antibodies. $C$, Control; glut, glutamate; NRS, normal rabbit serum. $B$, Relative levels of NF- $\kappa \mathrm{B}$ binding activity were quantified by phosphorimager analysis of the band corresponding to NF- $\kappa \mathrm{B}$ complexes. Data are the mean \pm SEM of three separate experiments, with two to three independent samples each experiment. ${ }^{* *} p<0.01$ versus glutamate (ANOVA and Dunnett's test).

2000), enhances neurological recovery after traumatic brain injury (Knoblach and Faden, 1998), or spinal cord lesion (Bethea et al., 1999) in rats. We suggest that IL-10 is an effective compound against EAA-mediated excitotoxicity.

Several growth factors-cytokines, in addition to IL-10, have been shown to prevent glutamate toxicity in cerebellar granule cells, among others BDNF and FGF2 (Fernandez-Sanchez and Novelli, 1993; Lindholm et al., 1993; Courtney et al., 1997; Marini et al., 1998). Indeed, we have reported recently that the neuroprotective activity of BDNF and FGF2 correlates with their ability to evoke a downregulation of the synthesis of NMDA receptor subunit NR2A and NR2C (Brandoli et al., 1998). Consequently, these growth factors decreased the abnormally sus-

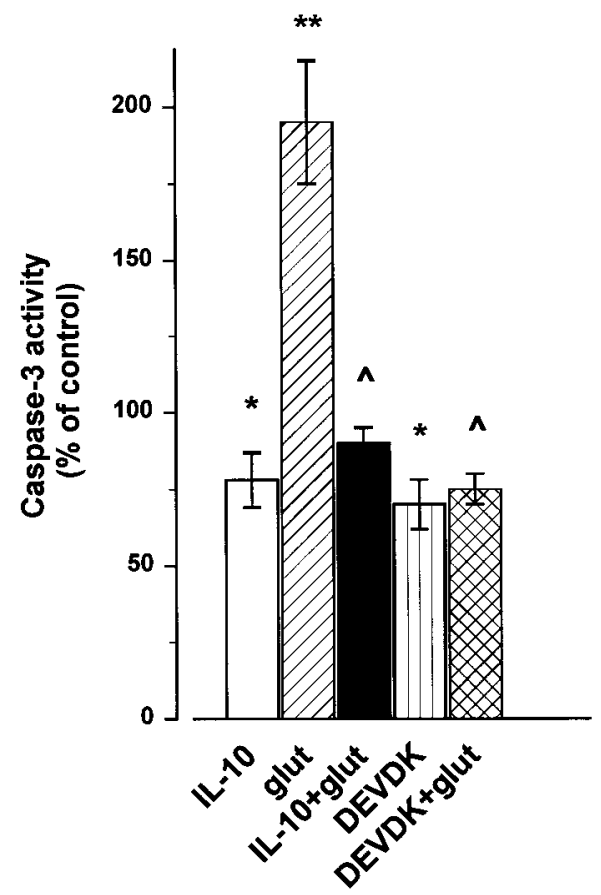

Figure 9. IL-10 prevents the increase in caspase-3-like activity evoked by glutamate ( glut). Cerebellar granule cells exposed to glutamate $(300 \mu \mathrm{M})$, $\mathrm{IL}-10(50 \mathrm{ng} / \mathrm{ml})$, or DEVDK $(100 \mu \mathrm{M})$ alone or in combination. IL-10 and DEVDK were added 10 min before glutamate. Caspase-3-like activity was measured $1 \mathrm{hr}$ later. Data are the mean \pm SEM of three independent preparations $\left(n=6\right.$ each group). ${ }^{*} p<0.01,{ }^{* *} p<0.005$ versus control; $\wedge p<0.005$ versus glutamate (ANOVA and Dunnett's test).

tained $\left[\mathrm{Ca}^{2+}\right]_{\mathrm{i}}$ typically seen after excessive stimulation of NMDA receptors (Brandoli et al., 1998) and implicated in neuronal cell death (Garthwaite et al., 1986; Rothman and Olney, 1986; Choi, 1988; Hahn et al., 1988; Anegawa et al., 1995). In contrast, neurotoxic cytokines, such as IL-6, has been shown to significantly potentiate NMDA-mediated increase intracellular calcium in cerebellar granule cells and, consequently, NMDAmediated excitotoxicity (Qiu et al., 1998). Thus, it was important to ascertain whether IL-10, a physiological anti-inflammatory cytokine, could prevent NMDA-mediated neurotoxicity by reducing NMDA current responses or $\mathrm{Ca}^{2+}$ influx. IL-10, used at a concentration and time effective against EAA-evoked cell death, failed to block glutamate or NMDA-mediated $\mathrm{Ca}^{2+}$ influx or NMDA-mediated Ifenprodil-sensitive membrane depolarization. Thus, our data exclude that the neuroprotective effect of IL-10 is attributable to a direct effect on the NMDA channel.

Apoptosis, in addition to toxic concentrations of EAA, can be caused experimentally by a wide variety of stimuli. However, each given cell type may use different molecular mechanisms to activate the cell death pathway. Cell death may be caspase-dependent or -independent and may involve a particular type of caspases. For instance, in cerebellar granule cells, caspase-3 does not appear to be involved in cell death evoked by serum deprivation (Miller et al., 1997). Instead, caspase-3, but not caspase-1, plays an important role in glutamate-mediated apoptosis (Du et al., 1997; Tenneti and Lipton, 2000). Evidence has also suggested that caspase-3 participates in apoptotic cell death after brain injury (Yakovlev et al., 1997) or ischemia (Cheng et al., 1998; Namura et al., 1998), indicating that caspase-3 plays a critical role in the terminal stage of the apoptotic pathway after CNS injury. In this report, we have shown that IL-10 prevents the increase in 


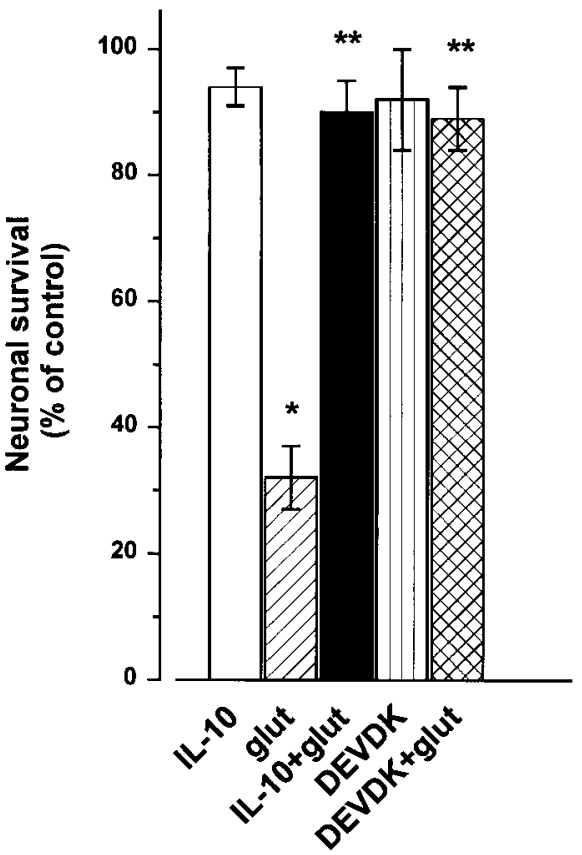

Figure 10. Inhibition of caspases prevents glutamate-mediated excitotoxicity. Cerebellar granule cells were exposed to glutamate (glut; $300 \mu \mathrm{M}$ ), IL-10 $(50 \mathrm{ng} / \mathrm{ml})$, or DEVDK $(100 \mu \mathrm{M})$ alone or in combination. IL-10 and DEVDK were added 10 min before glutamate. Cell survival was measured $14 \mathrm{hr}$ after by TUNEL assay. Data are the mean \pm SEM of three independent preparations ( $n=6$ each group). ${ }^{*} p<0.005$ versus control; $* * p<0.005$ versus glutamate (ANOVA and Dunnett's test).

caspase-3-like activity mediated by glutamate with a temporal profile and magnitude similar to that of DEVDK, a typical caspase inhibitor. In addition, IL-10 induced a rapid (within hours) decrease in caspase-3-like activity, regardless of its lack of effect on $\left[\mathrm{Ca}^{2+}\right]_{i}$, whose levels modulate caspase- 3 induction (Moran et al., 1999). Thus, it appears that IL-10 has an intrinsic ability to inhibit directly or indirectly caspase-3-like activity; this mechanism could explain the neuroprotective properties of IL-10 in vivo (Knoblach and Faden, 1998; Bethea et al., 1999; Grilli et al., 2000). It remains to be established whether IL-10 affects other caspases as well and the mechanisms whereby IL-10 reduces caspase- 3 activity in neurons.

Recent findings have implicated the transcription factor $\mathrm{NF}-\kappa \mathrm{B}$ as a mediator of neuronal apoptosis. Also, NF- $\kappa \mathrm{B}$ appears to have a deleterious role on neuronal survival. In fact, cell death occurs in neurons when NF- $\kappa \mathrm{B}$ is permanently activated, such as after trauma (Bethea et al., 1998), global ischemia (Clemens et al., 1998), or toxic concentrations of glutamate (Kaltschmidt et al., 1995; Grilli et al., 1996). On the other hand, inhibition of $\mathrm{NF}-\kappa \mathrm{B}$ activity results in inactivation of caspases (Gill and Windebank, 2000). IL-10 blocked the glutamate-mediated NF- $\kappa$ B DNA binding activity, shown previously to be causally involved in glutamate-mediated cell death (Kaltschmidt et al., 1995; Grilli et al., 1996). Thus, we provided additional support that the neuroprotective mechanism of this cytokine relies on its ability to interfere with the cellular mechanism involved in apoptosis. Interestingly, the suppression of NF- $\kappa \mathrm{B}$ DNA binding activity plays a role in the anti-inflammatory effect of IL-10 also in nonneuronal cells (Schottelius et al., 1999). Therefore, we speculate that IL-10, by reducing or preventing the activity of caspase- 3 and $\mathrm{NF}-\kappa \mathrm{B}$ evoked by EAA, reestablishes the physiological basal ratio of proapoptotic/antiapoptotic proteins that, in turn, may render neurons less vulnerable to apoptosis.

Our results might be of crucial neurological significance because effective therapies against post-trauma secondary injury in humans are still scarce. The findings reported here provide strong support to the belief that IL-10 may have a therapeutic significance for neurodegenerative diseases by blocking EAA-mediated excitotoxicity. However, we cannot definitively rule out the existence of other mechanisms that could account for the neuroprotective effect of IL-10. For example, the anti-inflammatory properties of IL-10 and its ability to decrease the synthesis of TNF- $\alpha$, IL-1 $\beta$ (Bogdan et al., 1992; Wang et al., 1994; Kline et al., 1995; Di Santo et al., 1997; Bethea et al., 1999, Sawada et al., 1999), or other cytokines such as FGF2 (Zocchi et al., 1997) or macrophage inflammatory protein-1 $\alpha$ (Berkman et al., 1995), may also help to reduce apoptosis. However, when we examined antiinflammatory neuroprotective compounds, such as methylprednisolone, we did not observed neuronal protection against glutamate (our unpublished observations). Moreover, astrocytes and microglia are mostly the primary sources of proinflammatory cytokines. Our neuronal cultures contain only few non-neuronal cells (at the most 5\%), thus, most likely do not contain toxic concentration of inflammatory cytokines. In conclusion, we propose that the neuroprotective effects of IL-10 against EAAmediated excitotoxicity is, at least in cerebellar granule cells, primary because of the ability of IL-10 to inhibit the activity of proapoptotic proteins and in particular caspase-3.

\section{REFERENCES}

Anegawa NJ, Lynch DR, Verdoorn TA, Pritchett DB (1995) Transfection of $N$-methyl-D-aspartate receptors in a nonneuronal cell line leads to cell death. J Neurochem 64:2004-2012.

Ankarcrona M, Dypbukt JM, Bonfoco E, Zhivotovsky B, Orrenius S, Lipton SA, Nicotera P (1995) Glutamate-induced neuronal death: a succession of necrosis or apoptosis depending on mitochondrial function. Neuron 15:961-973.

Baeuerle PA, Baltimore D (1996) NF- $\kappa$ B: ten years after. Cell 87:13-20.

Berkman N, John M, Roesems G, Jose PJ, Barnes PJ, Chung KF (1995) Inhibition of macrophage inflammatory protein-1 $\alpha$ expression by IL10. J Immunol 155:4412-4418.

Bethea JR, Castro M, Keane RW, Dietrich WD, Yezeirski RP (1998) Traumatic spinal cord injury induces nuclear factor-kB activation. J Neurosci 18:3251-3260.

Bethea JR, Nagashima H, Acosta MC, Briceno C, Gomez F, Marcillo AE, Loor K, Green J, Dietrich D (1999) Systemically administered interleukin-10 reduces tumor necrosis factor alpha production and significantly improves functional recovery following traumatic spinal cord injury in rats. J Neurotrauma 16:851-863.

Bettmann B, Henderson CE (1998) Neuronal cell death. Neuron 20:633-647.

Bogdan C, Paik J, Vodovotz Y, Nathan C (1992) Contrasting mechanisms for suppression of macrophages cytokine release by transforming growth factor- $\beta$ and interleukin-10. J Biol Chem 267:23301-23308.

Bonfoco E, Krainc D, Ankarcrona M, Nicotera P, Lipton SA (1995) Apoptosis and necrosis: two distinct events induced respectively by mild and intense insults with NMDA or nitric oxide/superoxide in cortical cell culture. Proc Natl Acad Sci USA 92:7162-7166.

Brandoli C, Sanna A, De Bernardi MA, Follesa P, Brooker G, Mocchetti I (1998) Brain-derived neurotrophic factor and basic fibroblast growth factor downregulate NMDA receptor function in cerebellar granule cells. J Neurosci 18:7953-7961.

Cheng B, Furukawa K, O'Keefe JA, Goodman Y, Kihiko M, Fabian T, Mattson MP (1995) Basic fibroblast growth factor selectively increases AMPA-receptor subunit GluR1 protein level and differentially modulates $\mathrm{Ca}^{2+}$ responses to AMPA and NMDA in hippocampal neurons. J Neurochem 65:2525-2536.

Cheng Y, Deshmukh M, D'Costa A, Demaro JA, Gidday J, Shah A, Sun Y, Jacquin MF, Johnson EM, Holtzman DM (1998) Caspase inhibitor affords neuroprotection with delayed administration in a rat model of neonatal hypoxic ischemic brain injury. J Clin Invest 101:1992-1999.

Choi DW (1988) Glutamate neurotoxicity and diseases of the nervous system. Neuron 1:623-634.

Clemens JA, Stephenson DT, Yin T, Smaltstig B, Panetta JA, Little SP (1998) Drug-induced neuroprotection from global ischemia is associ- 
ated with prevention of persistent but not transient activation of nuclear factor-kB in rats. Stroke 29:677-682.

Colangelo AM, Johnson P, Mocchetti I (1998) $\beta$-Adrenergic receptorinduced activation of Nerve Growth Factor gene transcription in rat cerebral cortex involves CCAAT/Enhancer binding protein $\delta$. Proc Natl Acad Sci USA 95:10920-10925.

Corsi L, JinHong L, Krueger KE, Wang YH, Wolfe BB, Vicini S (1998) Up-regulation of NR2B subunit of NMDA receptors in cerebellar granule neurons by $\mathrm{Ca}^{2+}$ calmodulin kinase inhibitor KN93. J Neurochem 70:1-9.

Courtney MJ, Akeman KEO, Coffey ET (1997) Neurotrophins protect cultured cerebellar granule neurons against the early phase of cell death by a two-component mechanism. J Neurosci 17:4201-4211.

De Bernardi MA, Rabin SJ, Colangelo AM, Brooker G, Mocchetti I (1996) TrkA mediates the nerve growth factor-induced intracellular calcium accumulation. J Biol Chem 271:6092-6098.

Di Santo E, Adami M, Bertorelli R, Ghezzi P (1997) Systemic interleukin 10 administration inhibits brain tumor necrosis factor production in mice. Eur J Pharmacol 336:197-202.

Du Y, Bales KR, Dodel RC, Hamilton-Byrf E, Horn JW, Czilli DL, Simmons LK, Binhui N, Paul SM (1997) Activation of a caspase 3-related cysteine protease is required for glutamate-mediated apoptosis of cultured cerebellar granule neurons. Proc Natl Acad Sci USA 94:11657-11662.

Fernandez-Sanchez MT, Novelli A (1993) Basic fibroblast growth factor protects cerebellar neurons in primary cultures from NMDA and non-NMDA receptor-mediated neurotoxicity. FEBS Lett 335:124-131.

Feuerstein GZ, Wang XK, Barone FC (1998) Inflammatory mediators and brain injury. In: The role of cytokine and chemokines in stroke and CNS diseases (Ginsberg M, Bogouslasky J, eds), pp 507-531. Oxford: Blackwell Science.

Garthwaite G, Hajos F, Garthwaite J (1986) Ionic requirements for neurotoxic effects of excitatory amino acid analogues in rat cerebellar slices. Neuroscience 18:437-447.

Gill JS, Windebank AJ (2000) Ceramide initiates NF-kB mediated caspase activation in neuronal apoptosis. Neurobiol Dis 7:448-461.

Grilli M, Pizzi M, Memo M, Spano P (1996) Neuroprotection by aspirin and sodium salicylate through blockade of NF-kB activation. Science 274:1383-1385.

Grilli M, Barbieri I, Basudev H, Brusa R, Casati C, Lozza G, Ongini E (2000) Interleukin-10 modulates neuronal threshold of vulnerability to ischemic damage. Eur J Neurosci 12:1-8.

Grynkiewicz G, Poenie M, Tsien RY (1985) A new generation of $\mathrm{Ca}^{2+}$ indicators with greatly improved fluorescence properties. J Biol Chem 260:3440-3450.

Hahn JS, Aizenman E, Lipton S (1988) Central mammalian neurons normally resistant to glutamate toxicity are made sensitive by elevated $\mathrm{Ca}^{2+}$ : toxicity is blocked by $N$-methyl-D-aspartate antagonist, MK801. Proc Natl Acad Sci USA 85:6556-6560.

Hara H, Friedlander RM, Gagliardini V, Ayata C, Fink K, Huang Z, Shimizu-Sasamata M, Yuan J, Moskowitz MA (1997) Inhibition of interleukin-1 beta converting enzyme family of proteases reduces ischemic and excitotoxic neuronal damage. Proc Natl Acad Sci USA 94:2007-2012.

Kaltschmidt C, Kaltschmidt B, Baeuerle PA (1995) Stimulation of ionotropic glutamate receptors activates transcription factor NF-kB in primary neurons. Proc Natl Acad Sci USA 92:9618-9622.

Kline JN, Fisher PA, Monick MM, Hunninghake GW (1995) Regulation of interleukin-1 receptor antagonist by Th1 and Th2 cytokines. Am J Physiol 269:92-98.

Knoblach SM, Faden AI (1998) Interleukin-10 improves outcome and alters proinflammatory cytokine expression after experimental traumatic brain injury. Exp Neurol 153:143-151.

Lindholm D, Dechant G, Heisenberg CP, Thoenen H (1993) Brain derived neurotrophic factor is a survival factor for cultured rat cerebellar granule neurons and protects against glutamate-induced neurotoxicity. Eur J Neurosci 5:1455-1464.

Liu XZ, Xu XM, Hu R, Du C, Z hang S, McDonald JW, Dong HX, Wu YJ, Fan GS, Jacquin MF, Hsu CY, Choi DW (1997) Neuronal and glial apoptosis after traumatic spinal cord injury. J Neurosci 17:5395-5406.
MacDermott AB, Mayer ML, Westbrook GL, Smith SJ, Barker JL (1986) NMDA-receptor activation increases cytoplasmic calcium concentrations in cultured spinal cord neurons. Nature 321:519-522.

Marini AM, Spiga G, Mocchetti I (1997) Toward the development of strategies to prevent ischemic neuronal injury. Ann NY Acad Sci 825:209-219.

Marini AM, Rabin SJ, Lipski R, Mocchetti I (1998) Activity-dependent release of BDNF underlies the neuroprotective effect of NMDA. J Biol Chem 273:29394-29399.

Mattson MP, Murrain M, Guthrie PB, Kater SB (1989) Fibroblast growth factor and glutamate: opposing roles in the generation and degeneration of hippocampal neuroarchitecture. J Neurosci 9:3728-3732.

Miller TM, Moulder KL, Knudson M, Creedon DJ, Deshmukh M, Korsmeyer SJ, Johnson EM (1997) Bax deletion further orders the cell death pathway in cerebellar granule cells and suggests a caspaseindependent pathway to cell death. J Cell Biol 139:205-217.

Mocchetti I, Wrathall JR (1995) Neurotrophic factors in central nervous system trauma. J Neurotrauma 12:853-870.

Moran J, Itoh T, Reddy UR, Chen M, Almeri ES, Pleasure D (1999) Caspase-3 expression by cerebellar granule neurons is regulated by calcium and cyclic AMP. J Neurochem 73:568-577.

Murase K, Ryu PD, Randic M (1989) Excitatory and inhibitory amino acids and peptide-induced responses in acutely isolated rat spinal dorsal horn neurons. Neurosci Lett 103:56-63.

Namura S, Zhu J, Fink K, Endres M, Srinivasan A, Tomaselli KJ, Yuan J, Moskowitz MA (1998) Activation and cleavage of caspase-3 in apoptosis induced by experimental cerebral ischemia. J Neurosci 18:3659-3668.

O'Neill LAJ, Kaltschmidt C (1997) NFkB: a crucial transcription factor for glial and neuronal cell function. Trends Neurosci 20:252-257.

Qiu Z, Sweeney DD, Netzeband JG, Gruol DL (1998) Chronic interleukin-6 alters NMDA receptor-mediated membrane responses and enhances neurotoxicity in developing CNS neurons. J Neurosci 18:10445-10456.

Resink A, Hack N, Boer GJ, Balázs R (1994) Growth conditions differentially modulate the vulnerability of developing cerebellar granule cells to excitatory amino acids. Brain Res 655:222-232.

Rothman SM, Olney JW (1986) Glutamate and the pathophysiology of hypoxic-ischemic brain damage. Ann Neurol 19:105-111.

Sawada M, Suzumura A, Hosoya H, Marunouchi T, Nagatsu T (1999) Interleukin-10 inhibits both production of cytokines and expression of cytokine receptors in microglia. J Neurochem 72:1466-1471.

Schottelius AJG, Mayo M, Sartor BR, Baldwin AS Jr (1999) Interleukin-10 signaling blocks inhibitor of $\mathrm{kB}$ kinase activity and nuclear factor kB DNA binding. J Biol Chem 45:31868-31874.

Schramm M, Eimerl S, Costa E (1990) Serum and depolarizing agents cause acute neurotoxicity in cultured cerebellar granule cells: role of glutamate receptor responsive to $N$-methyl-D-aspartate. Proc Natl Acad Sci USA 87:1193-1197.

Spera PA, Ellison JA, Feuerstein GZ, Barone FC (1998) IL-10 reduces rat brain injury following focal stroke. Neurosci Lett 251:189-192.

Tenneti L, Lipton SA (2000) Involvement of activated caspase-3like proteases in $\mathrm{N}$-methyl-D-aspartate-induced apoptosis in cerebrocortical neurons. J Neurochem 74:134-142.

Wang P, Wu P, Siegel MI, Egan RW, Billah MM (1994) IL-10 inhibits transcription of cytokine genes in human peripheral blood mononuclear cells. J Immunol 153:811-816.

Wielock T (1985) Hypoglycemia-induced neuronal damage prevented by a $N$-methyl-D-aspartate antagonists. Science 230:681-683.

Williams K (1993) Ifenprodil discriminates subtypes of $N$-methyl-Daspartate receptors: selectivity and mechanism at recombinant heteromeric receptors. Mol Pharmacol 44:851-859.

Yakovlev AG, Knoblach SM, Fan Lei, Fox GB, Goodnight R, Faden AI (1997) Activation of CPP32-like caspases contributes to neuronal apoptosis and neurological dysfunction after traumatic brain injury. J Neurosci 17:7415-7424.

Zocchi C, Spiga G, Rabin SJ, Grekova M, Richert J, Chernyshev O, Colton C, Mocchetti I (1997) Biological activity of interleukin-10 in the central nervous system. Neurochem Int 30:433-439. 